\title{
Towards a Kenyan political theology: The importance of church history for contemporary public life
}

\begin{abstract}
Kevin Muriithi Ndereba
Department of Biblical and Theological Studies, School of Theology, Pan Africa Christian University, Nairobi, Kenya.

Received 12 June, 2021; Accepted 15 September, 2021

Christianity remains a substantive religion in the African continent. With various expressions such as missionary Christianity, indigenous Christianity, and Charismatic Christianity, it remains a critical force in African societies. Christian scholars in post-colonial Africa have engaged important themes in Christianity including the pertinence of African traditional religions, African identity and in the recent decade, postcolonial hermeneutics, and approaches to reading the Bible. Whereas a majority of Kenyans are Christians, there seems to be little evidence in how Christianity engages the politics of the day. It is argued that African Christians, contrary to the historical development of Christianity as well as the holistic worldview of African traditional cultures, have bi-furcated their religion to a private sphere. This paper explores the rich developments of political theology in church history, with particular reference to key African theologians and scholar-practitioners such as Emmanuel Katongole, Sammy Gitari, Damaris Parsitau and Timothy Njoya. By retrieving the global church's historical thinking on the matter, this paper explores the implications for African societies, including the church, theological institutions, and public life.
\end{abstract}

Key words: African Christianity, African theology, church and state, political theology, religion and society, world Christianity.

\section{INTRODUCTION}

\section{Trajectories of African Christianity}

Christian demographics in Africa are a strong rebuttal to the enlightened Western philosophers, who concluded on behalf of the world, that "God is dead" (Nietzsche, 2005). Further, religion continues to play a critical function in African societies, from the initiatory rites such as birth, initiation, marriage, and death, to more political and public activities such as presidential campaigns, organizational banquets, and public education systems.
Although there is a tide of rising secularism in the form of Atheist societies in most African cities, the African theologian John Mbiti's claim, "Africans are religious", is still representative of the continent (Mbiti, 1990). Religion is not going anywhere. Christian theologians have observed the phenomena that the center of the Christian faith has moved to the global South, and the trajectories for the next three decades portray a large presence of

Email: kevin.ndereba@pacuniversity.ac.ke. Tel: +254 780934743.

Author(s) agree that this article remain permanently open access under the terms of the Creative Commons Attribution License 4.0 International License 
Christianity in the continent. In terms of numbers in global Christianity, as of 2018, there were 599 million Christians in Africa, compared to 597 in Latin America and 550 million in Europe (Johnson et al., 2018). In 2050, the global studies place African Christianity at 1.25 billion, which is almost double the figure in Latin America, 705 million, and triple that in Europe, 490 million (Johnson et al., 2018). The point is that statistically, Christianity in Africa is heading upward.

Unraveling the statistics reveals that expressions of African Christianity are broad. Following the missionary enterprise into the continent in the medieval period through Portuguese missions, and returning again in the 1800-1900s, "mainstream" Christianity can be found in most African societies. These include Roman Catholics, Anglicans, Presbyterians, Methodists, and Lutherans, among others. In post-colonial Africa, a response to this formative expression of the faith saw the rise of indigenous Christianity, which was a form of contextualization of the Christian faith into African liturgical forms, languages and even missions. The rise of Pentecostalism, in the first wave and then the consequent rise of Charismaticism within mainstream Christianity in consequent waves are also markers of African Christianity today. Indeed, African Christianity has varied trajectories (Adogame, 2016).

One of the critical factors to consider is how this quantitative trajectory of Christian faith in the continent is not transforming into qualitative transformation within African societies. Following the argument, African nations that have a significant Christian presence, are still the nations that struggle with high levels of corruption, political and ethnic violence as well as concerning healthcare systems. The question begs, how is it that these "Christian nations" are not spearheading widescale changes in healthcare systems, transformative leadership as well as social enterprise that benefits the people? How come in a country such as Rwanda that was $90 \%$ Christian according to her 1991 census, be the same country renown for mass murder and genocide in 1994, with Churches even used as killing grounds? How is it that "people came to mass each day then they went out to kill", as Longman (2010) notes in his book Christianity and Genocide in Rwanda?

The 1994 genocide of the Tutsis is a marker of how political powers intertwine seamlessly with religion, thereby raising the focus on church-state relationships within our contemporary societies. Here in Kenya, similar violence erupted in the 2007 General Elections between the Kikuyu and Kalenjin ethnicities, with ongoing tensions among the two in the country's political discourse. Although Longman (2001) observes that a proper response to some of Africa's ills such as the genocide requires a consideration for church and state, he helpfully locates the foundation stone as a proper understanding of what the church is. While his point is valid, understanding the church cannot preclude understanding church-state relationship since while the church is ultimately a spiritual entity, she is located within geographical boundaries of time and space.

\section{Is Christianity private or public?}

The problem that this paper seeks to research is why the relationship between church and state, is an oxymoron in Africa. The author argues that the reason Christianity has failed to engage the political sphere from an ethical perspective has to do with an expression of Christianity that is largely individualistic. Such a privatized Christianity fails to consider the pertinent relationship of Church and State in Christian history and the forerunner African theologians who have proposed a healthy interaction between the two. The rest of this paper will explore how the global church has a rich heritage in the area of political engagement as well as how African theologians have engaged with the issues, with particular reference for the Kenyan society.

\section{TOWARDS A POLITICAL THEOLOGY}

Political theology may be approached from various vantage points. The underlying assumption is that political theology has to do with how the sacred functions within human action, and vice versa (Cavanaugh and Scott, 2019:3). The first approach, following the "secularization theory" in sociology of religion, explores the boundary between politics and theology, and therefore studies politics in a secular sense - that is, in terms of how the state functions in its grouping of people, communities and institutions, outside references of the divine. The second approach, according to Cavanaugh and Scott (2019:4) engages politics from the theological standpoint and seeks to give a positive or negative account of how political power is wielded by the state on its actors. A third approach blurs the line between politics and theologies, viewing them as synonymous activities that seek to produce "metaphysical images around which communities are organized" (Cavanaugh and Scott, 2019:4).

From the literature, political theology has developed as a form of political theory that seeks to speak into Christian sensibilities. An example of the third approach can be gleaned from Dube's (2020) definition of African political theology as:

A primarily Christian enterprise that, in particular, decentres the state in African politics and, consequently; centres the everyday African historical reality of justice seeking; as well as takes seriously the particularity of necropolitics.

Dube's "foray into Christian African political theology" speaks only to the outworking of what ethical political 
action could take in the society. He explores the political theologies of Elias Bongmba and Emmanuel Katongole to make his case. While Bongmba focuses on the state as the subject which Christian faith must critique and influence, Katongole focuses on a new socio-political imaginary of the church itself (Dube, 2020:653). Likewise Longman (2001:165) also engages political theology from the political standpoint when he explores how political scientists have analysed the religious underpinnings of Rwanda's genocide. These divergent approaches look at religions as social markers and how they function within political groupings and even mobilizations.

As a theologian, the author takes the second approach of political theology - that is exploring the current state affairs from the lens of theology. He looks at the history of Christian theology and traces certain markers that may help us explore a healthy relationship between Church and State. In particular, he will explore the thinking of key theologians in Africa and specifically, those who have not only written about but also acted from within their developed political theology. The author's argument is that unpacking the rich heritage of the church and the continent creates a fertile resource for engaging in contemporary justice issues within African societies. From this thinking, Christianity not only has to do with an individualistic ethos but is by its very core, public and political in nature.

\section{Religion and politics in the biblical canon}

From a cursory approach, the relationship between Church and State may be developed from the New Testament. After all, some argue that Acts 2 is the epicenter of the formation of the Church in the New Testament. However, the Old Testament is critical in developing a contemporary theology for church and state (Beckwith, 2008; Kaiser, 2003). Thus, the moral code of the Mosaic covenant still applies to the Church today even though that understanding is enriched by the Mediator of the New Covenant. The point therefore is that if we envisage Israel as God's people in the Old Testament, then it can explore certain themes of ChurchState relationship from the Old Testament, or contra- an anachronistic reading, how religion relates with politics.

As a nation, Israel organized itself around land, goods, and codes of ethics. As the Old Testament scholar Walter Brueggemann (2019) observes:

Like every political community, ancient Israel had to devise institutions, policies, and practices that apportioned power, goods, and access in a manageable, practicable, sustainable way. And, as in every such community, those ways of managing were endlessly under review and sometimes under criticism and assault.

From the perspective of Israel, the relationship between
Judaism and politics is organized around monarchical rule (1 Sam 7-15). Secondly, based on the socioeconomic differences inherent in the Israelite community, ethical codes were central in how the rich and the poor should function. Both within the monarchy and the divided kingdom, there are strong calls for advocacy of "widows, orphans, sojourners, and the poor" (Deutoromy, 15:1-8; Isaiah, 42:1-9). In fact, as Brueggemann (2019) observes, prophetic ministry in the Old Testament is a recasting of social justice against the political class of the day - even in exilic and post-exilic Israel (Isaiah, 5: 8-10; Micah, 2: 1-4; Jeremiah, 5: 27-9 and Isaiah, 61: 1-4; Zechariah, 7: 9-12; Daniel, 4: 27).

We could also think of how the kingly, priestly, and prophetic offices function in the Old Testament and their implications for Church- State relations. The priests mediated God's law to the people and were in charge of the religious and liturgical life of the Israelites. The kings were mandated to rule well for the well-being of all people. The prophets were tasked with calling the Israelites to fidelity to God's covenant with them. As such, these three offices played mutually beneficent roles. Within the biblical canon, it is from the vantage point of the life and ministry of Jesus Christ that we see how the three offices function. In the New Testament, we see how political leaders sometimes aid the church and other times curtail the church's mission. This can be seen in Jesus' interaction with the political and religious classes of the day - the Pharisees and Sanhedrin - as well as Paul's interaction within the Roman Empire (Matthew, 23, 26:1-5; Acts, 25-28). Rowland (2019:29) argues from Acts $5: 29$ that the early church can be understood as a subservient force within the Roman Empire. Within the corpus of Pauline epistles, the passage of Romans 13:17 has been salient for political theology. His use of "citizenship" in Philippians is also helpful in articulating how the Church and State could relate for individual Christians - because they inhabit, as it were, two kingdoms. The same train of thinking is further developed by the writer to the Hebrews in 12:18-28. These themes offer wide application for the implication of Church-State relationship from the biblical perspective.

\section{Church-State relations in the early church}

This part of the study looks at representative theologians in each period of Christianity. These are Augustine in the early church period (AD 0-500), Thomas Aquinas in the medieval period (AD 500-1500) and Martin Luther in the Reformation period (1500-1700). Augustine of Hippo was an African theologian and bishop in Roman-occupied Africa. His major works are the Confessions and City of God. The latter especially contains his political theology and has been the subject of much political and theological reflection. The City of God was the result of Augustine's thirteen years of intellectual labor (AD 413 - 
426). It has been widely received in the East and West, and within Roman Catholic and Protestant churches through key figures such as Bossuet, Ozanam, Frederick Schlegel, Waterland, Milman, Neander, Bindemann and Pressensé (Schaff, 3). Written to his friend Marcellinus, it was a response against those who rejected God for the gods of the city (Schaff, 17). In this self-declared preface, Augustine already acknowledges the state as having its sovereignty from God. In his book IV, he speaks in clear terms when he says that "the Roman empire is to be ascribed to ... the one true God, the author of felicity, by whose power and judgment earthly kingdoms are founded and maintained" (Schaff, 159). Hallencreutz (1988:13) gives us a mosaic of the socio-cultural and political makeup of the Roman Empire at the time, which read as the context of Augustine's thoughts reveal that Augustine's treatise is as subversive as his forbearers:

At that time the structures developed after the Punic Wars in what became Roman North Africa had begun to crumble. There was still a dominant Roman upper class comprising higher colonial administrators (such as Volusianus), landlords and merchants who maintained close links across the sea with Italy and Imperial Rome. There had also emerged a substantial Latin-speaking Roman Berber middle class - a 'Coloured'. Community, if you wish - which was Augustine's own social background and which became his particular congregation. Then there were Berber farm-labourers dominating the lower classes. Further south, into what is today the Sahara, traditional modes of production prevailed.

Towards the end of the fourth century there had been national uprisings in Roman North Africa. The Donatist movement, forced underground when Constantine's religious policy was applied in the North African provinces and which became even more vulnerable after Theodosius the Great, was sympathetic to the nationalist cause. During the 420s, Germanic Vandals adhering to an Arian form of Christianity travelled via Spain and invaded Roman North Africa from the west in order to secure a foothold for attacks against Rome. It is under such circumstances that Augustine ministered as Bishop of Hippo Regius for thirty-five years.

Such a lens allows for proper political action while ensuring that the ends of political power are for the eternal purposes of God - in the here and now, justice to all people within the state. According to Augustine, the earthly cities (and by extension) states, function within the providence of God (Hallencreutz, 1988:16). Some have studied Augustine as a migrant thereby expanding the viewpoint of the City of God to make room for a socially engaged political theology (Hannan, 2021:12). These insights show us that theology is by necessity political, and that politics is by necessity theological. Thus, political theology is the bridge through which Christian individuals and institutions can take up redemptive action within the spheres that they influence.

\section{Church-State relations in the medieval period}

Thomas Aquinas (AD 1225-1274) has left a remarkable legacy for the church at large. His Summa Theologica and Summa Contra Gentiles are landmark works in Christian literature and theology. This "Doctor Angelicus" has received contemporary reception from a variety of quarters, including "Natural law", legal and political theorists as well as liberation theologians (Bauerschmidt, 2019:54). Bauerschmidt (2019:59) distils Aquinas' political theology to two main themes. First, he portends that theological truth encounters and enraptures worldly power. Aquinas' commentary on the gospel accounts of Jesus with Pilate in John 18:33, 19:22 reveals that the power of truth is seen in its eternality, unlike the power of an earthly ruler like Pilate, which is limited to the physical realm.

The second theme of natural law is viewed contextually within the whole Summa and Bauerschmidt contends that Aquinas approaches the natural law only in the subtext of the eternal law of God. Thus, according to Bauerschmidt, human action that is predicated on the intellectual response of human beings does not occur on a humanistic interpretation of "natural law" but anchored on God's divine law. And thus, political action, viewed from the divine lens, is by very nature acting in accordance with the human instinct to pursue that which is good - of course, this would differ from the assumptions within Protestant anthropology that is founded on the concept of total depravity. Nonetheless, natural law is seen as a philosophical framework for political theology.

\section{Church-State relations in the reformation era}

The 16th Century Reformation has been interpreted as a bedfellow to individualistic religious views as well as isolationist spirituality. The reason is that the magisterial reformers such as Luther, Calvin, Bullinger, Knox and others reframed the understanding of Christian doctrine as primarily centred on one's relationship with God. Considering the excesses allowed by the Roman Catholic Church the reformers chatted a new path in the understanding of the Church. Thus, a cursory consideration may see their political theology as one of political action to liberate those in the margins - in this case, Christians who could neither read their own Bibles in their mother tongues or were in slavery to a spiritual and economic system that destined them to the dark world, as it were. However, a keen reading of Martin Luther (AD 1483 - 1546) and a contextual understanding of his role as a Roman Catholic priest would dissuade one from an overly individualistic interpretation of the reformation. The development of a robust doctrine of the 
church among the other protestant reformers, particularly John Calvin has been instrumental in the organization of reformed churches. In fact, contemporary, confessional Presbyterian Christianity is one of the best models of shared leadership within institutions and organizations.

Thus, Martin Luther has contributed several themes in the area of political theology. First, is the fact that individuals are also sovereign and that states should function for their well-being (Bradstock, 2019). This provides a critical viewpoint for African states, where political leaders wield power to subjugate people. Secondly, Bradstock (2019) asserts that Luther's reformed theology is also foundational for democratic notions of authority. Thus, whereas Augustine's political theology was written within the Constantin Empire, the "two kingdoms" theory was not as clearly developed as with Martin Luther's timeline. Therefore, Luther develops this theory further by noting that although Christians indwelt by the Spirit are ruled by a higher "ethic of love", other state citizens are not. Therefore, the function of the state or government is critical for the purposes of ensuring order within pluralistic societies. Thus, Luther made a distinction (not an original one, as Augustine and Ockham before him already had) between the sacred and secular. However, it was clear from the reformation that there were levels of interaction between the two spheres (Bradstock 2019; Leeman, 2016). Additionally, the Protestant Reformation has been interpreted as a political movement, shifting power structures within the ecclesiastical body of the day, mediated through the crucial support of key figures of the time such as Marguerite d'Angoulême AD 1492-1549, Queen of Navarre after her marriage to Henri d'Albret in 1527, and her evangelical network in the case of the French reformation (Tulchin, 2014:831). After all, as Bradstock (2019) argues, the Protestant reformation is in essence a series of "reformations" - a "bewildering array of related movements, sometimes correlating and sometimes contrasting, unfolding at different paces and in different stages across the widely varied social and political landscape of early modern Europe."

\section{Church-State relations in African theology}

Within the continent, political theology speaks to the diverse and dreary narratives within pre-colonial, colonial, and post-colonial history. Katongole (2019), one of Africa's prominent political theologians notes the earlier contradictions I offered when he says that Africa is simultaneously a 'continent of coffins and of churches'. Katongole's (2011:59) approach seeks to offer a better vision for how theology is critical in reimagining social ethics in the continent. This is the only way, according to Katongole (2011:1), of sufficiently dealing with this oxymoron of growing Christian presence in Africa with violence, civil unrest, poverty, tribalism, and corruption. In
Katongole's (2011) thinking, such a political imaginary is only possible when African Christians give a reason for the hope they have (1 Peter, 3:15) - This to me is a remarkable way of moving from the private to the public sphere in Christian confession, much like Peter intended for his audience in his epistles.

In his survey of political theology in modern African states, Katongole (2019:348-352) explores how the church has responded in a threefold manner - he catalogues these three responses as deeper evangelization, political advocacy, and development. The first response arises from churches that view their core role as merely a sacred role. Thus, their response to the socio-political crises of our nations stem from the fact that people are not sufficiently evangelized. The second response of political advocacy is undergirded by the liberationist and reconstructionist theologies among postcolonial African theologians. Borrowing the motifs of the Exodus in the case of liberation, and the motifs of the post-exilic Israel in the case of reconstruction, these theologies have been appropriated to womanist thought in Africa (for instance in the works of Musa Dube), critique of neo-colonial dependence (for instance in the works of Jean Marc Ela and Engelbert Mveng') and pulpit preaching that calls out political injustice (for instance in the ministries of Bishop Alexander Muge and Rev. Dr. Timothy Njoya in Kenya). The third response according to Katongole (2019) is one that seeks to remedy the gaps in the social services of African states including the construction of educational institutions and hospitals.

Katongole (2019) also views Pentecostal / Charismatic Christianity as a form of political theology in its appropriation of modernity. In one sense, as a political movement within mainline Christianity, it has contextualized the Christian faith in languages, expressions and liturgies that are curated by Africans themselves. On the other hand, by over-emphasizing the pressing problems of Africans, it has been used as a tool to oppress poor people in Africa. Katongole's (2019:353) interpretation of Pentecostal theology of salvation (or soteriology) is helpful:

Two basic understandings of salvation - salvation as an inner spiritual experience and salvation as an outer material/physical experience - are prevalent within neoPentecostal theology and help to explain the emphasis on prosperity. The inner experience of being born again through the Spirit presupposes and involves redemption from physical powers and structures that induce ill health and poverty. Accordingly, poverty is not only a physical/economic reality, but also a spiritual reality.

Emmanuel Katongole correctly observes that this sort of theology is attractive to both the upwardly mobile African as well as the poor African. However, this form of theology, which may even court power for the sake of prosperity, lacks the rigor to critique political excesses. 
Thus, Katongole (2019) argues that Pentecostal Christianity cannot be thoroughly envisaged as a political theology that calls African states to moral culpability.

\section{Church-State relations in Kenyan Christianity}

The history of Kenyan Christianity can be demarcated as pre-colonial (Before, 1963) and post-colonial periods (After, 1963). Within the post-colonial Christian enterprise, different expressions of Christianity have taken shape as has been argued before. In Kenya, the mainstream churches include Presbyterian, Anglican, Roman Catholic, Eastern Orthodox, Lutheran, and Methodist among others. The African Indigenous Churches (AICs) are usually Pentecostal in expression, with a variety of formal and informal liturgies and ecclesiology. The understanding of Church and State in the country can further be explored as pre-colonial period under the British protectorate (1895-1963), Jomo Kenyatta regime (1963-1978), Moi regime (1978-2002), Kibaki regime (2002-2007) and Uhuru Kenyatta regime (2007-present).

Considering the pre-colonial period under the British protectorate (1895-1963), tensions colored the relationship between "the British man's" church and the African people. Fermented under the freedom struggle of the Mau-Mau, the tensions arose from the fact that some of the Home Guards were missionary Christians (Gathogo, 2014:22). On the other hand, the Mau-Mau resisted the political apparatus of the colonial enterprise which was interpreted to be in tandem with the Christian missionary enterprise. As a result, Mau-Mau fighters rejected the entire enterprise, and even injured and burned people and property. Gathogo (2014) records that as a response to the entire movement, and to the oathing ceremonies in particular, the mainline churches and the Roman Catholic churches publicly rejected the oathing system. Although the Christian missionary enterprise was formative for the development of the African churches, schools, and hospitals, it was shrouded with a substantial level of tension. The tension is understandable especially given the context of Kenya's traditional societies that existed fairly close to one another - with different sociocultural and political organizations - and thereby influenced by the environments they lived in. Kamaara (2010:130) for instance observes that since the Luos lived near a water body they engaged in fishing; likewise, the Bantu tribes such as Kikuyu and Meru, engaged in farming due to their location; and Maasai were pastoralists. Through the colonial enterprise, boundaries divided people along ethnicities, socio-cultural and economic make-up.

With the turn of the independence, the leadership of the Churches took on an indigenous face. Parsitau (2012) infers that since a number of the early African church leaders were in the same ethnicity with the founding President, Jomo Kenyatta, Church-State relationship in that time can be described as "quiescent". In fact, Kaamara $(2010,134)$ argues that since the colonial enterprise was concentrated along the GEM towns (Gĩkũyũ, Embu and Meru) these ethnicities were able to develop faster than the other ethnicities in the country. Unfortunately, in the history of Kenyan Christianity, the formation of denominations has largely coincided with this ethnic bent. As such, the Presbyterian Church of East Africa (PCEA) is largely Kikuyu, the Seventh DayAdventists (SDA) is largely Kisii and the Friends Church or Quakers are largely Luhya. Thus Church-State relations in Africa began with a bias towards ethnicity, and still affect the contemporary view on political thought and action.

The significance of the Moi regime (1978-2002) to Kenya's political definition is the concept of the singleparty state, mandated in 1985, and the consequent democratic push by civil and religious organizations. Thus, Churches responded to this "Nyayo philosophy" by organizing themselves and pushing for reforms, in pulpits and in the public. Parsitau $(2012,2)$ observes the critical role that the Church played in the constitutional reforms. The civil society of the time actually called the Church to this "political action" because of its wide and unified network. This was the precursor to the formation of the National Council of Churches of Kenya (NCCK), with 1,200 religious ministers attending its inauguration (Kamaara, 2000, 168). Karanja (2008:70) observes that initially, it had been known as the Council of Churches of Kenya (CCK) which was formed in 1943 as a basis of cooperation between the Protestant churches. Bishop David Gitari and Alexander Muge were key clergy who led their churches (Anglican Church of Kenya) in this new agenda of political theologizing and action. Karanja (2008:80) records how on July 28, 1985, David Gitari, then Bishop of Mount Kenya region, preached a courageous sermon from Philippians 4:1-9 on justice and righteousness as the centerpiece of a healthy nation, with clear calls to the warring political leaders of the day in attendance.

Within the Presbyterian Church of East Africa, the infamous Rev. Dr. Timothy Njoya was at the forefront of crafting a political theology for Church-State relations. Njoya had already argued in 1998 that "the first thing Christianity did in Africa was to make people surrender their sovereignty to church hierarchies and governments. African dictators did not learn any lessons in democracy from the way churches were established, like fiefdoms" (Njoya, 1998). More recently, Njoya (2017) envisages his political theology as a movement of sovereign power moving from the state, as European machinery, to the people. Both Gitari (1991) and Njoya (1998), are remarkable examples of how one could develop a "political theology" that is deeply theological and thereby not merely a political theory but one conversant with God's action in the world - Although Njoya utilizes the doctrine of divine sovereignty and Gitari eclectically uses 
the fourfold doctrines of God, humanity, creation, and kingdom of God, they both call African Christians to political engagement. In their own words:

While God becomes human and accountable without losing God's integrity, the church fears incarnation out of fear of losing its western identity. By not accepting liability for the ravages of capitalism and imperialism, the church becomes a liability. Christianity should stop playing the role of maintenance and repair in the capitalist system. The church cannot cure western guilt with charity, poverty alleviation projects, contextualization, indigenization, or Africanization programmes. These are symptoms of the governance-deficiency syndrome and the accountabilityavoidance spirituality bequeathed by western history. God's death and resurrection take place in all cultural, political, institutional, and personal situations. The gospel has a life-death-resurrection dynamics of its own and charts its own development. The gospel is for enabling, changing, and helping people with the example of how a weak and vulnerable God who became a prisoner, hungry and naked overcame death (Njoya, 1998).

The doctrine of creation reminds us that God not only creates but sustains his creation; the doctrine of humanity reminds us that God commanded humans to take part in his creativity; the doctrine of incarnation reminds us that God took residence among us and spoke on the stage of human history; the doctrine of the Kingdom of God shows us how Jesus was involved in the social, political, economic and spiritual affairs of the world. These have been the theological roots of my involvement in the public life of Kenya, in particular in debate over the queuing system in national elections between 1985 and 1990 during which my life was threatened (Gitari, 1991).

In addition, the 1990s saw the mushrooming of the Structural Adjustment Programmes (SAP) by key corporations that affected the political and economic landscape of the country. These Kenyan Christian leaders were therefore critical in the democratization process of the country as a "voice of the voiceless and the conscience of society" (Parsitau, 2012).

In addition to the political theology of the Anglican cleric Okullu (1991), these Christian leaders are exemplary in the development of a political theology for Africa at large, and Kenya in particular.

\section{A CALL FOR AFRICAN (KENYAN) CHRISTIANITY AND THEOLOGY}

Following these luminary theologians, the consequences for a Kenyan political theology are plenty. The doctrine of God's sovereignty reminds people that both the Church and State find their being in God. This means that both are accountable to God for both their independent functions and their inter-dependent functions. Secondly, the doctrine of creation means that God has vested stewardship of these two spheres to human beings, created in his image. As co-regents with God, human beings should act in a manner that honours the Sovereign. Third, the doctrine of incarnation bequeaths an understanding of the "towel" to both the Church and State - both are to be servants of the people, wherever they are incarnated in the world. Lastly, the doctrine of the Kingdom of God grants an eschatological perspective to both the Church and State, thereby ensuring that their service is not selfish but as per Njoya's (2017) words, it is for "we the people".

Of course, envisaged as a type of practical theology, political theology is not done in isolation. With Bongmba (2019) I would contend that there is value in interdisciplinary engagement, particularly the social sciences. However, this paper has revealed that the historical-theological development of the Church bequeaths us with wisdom to navigate the oftencontested space of Church and State. The implications for these are as follows:

1) African Christians and theologians, following Katongole's argument, must pursue a new "political imaginary" anchored on hope. This is the only mode for maintaining Christian witness during times of great political unrest and global pandemic. Our Christian engagement must be for the purpose of "giving the reason for the hope that we have" (1 Peter, 3:15).

2) Theological institutions are called to consider the value of history for the issues that are being faced today. By surveying Church-State relations in the history of the Church among key theologians such as Augustine, Aquinas and Luther, this paper has revealed that the Church and academy do not exist in isolation.

3) African theologizing must never throw away the baby with the bath water. While there are many traumas inherited from our past, we must engage in the hard work of separating the "meat from the bones". This kind of approach retrieves classical theological reflection as well as how that enterprise has been conducted by Africans within different socio-cultural contexts. Katongole, Gitari and Njoya have been used as an example of mapping out a distinctively Christian and African (Kenyan) political theology.

4) Political theology, making use of political theories, historical precedents, and theological, biblical, and confessional resources must attend to real issues that the Church and State faces. In Kenya for example, a political theology must continue to reimagine and to negotiate issues of negative ethnicity, corruption, tribalism, poverty, and power. What good would be our Christianity if it is merely sang on Sunday? Isn't what it means to be follower of Jesus Christ, portraying by life and deeds, in public from Monday to Saturday, the triad of "faith, hope and love"?

All theology is political, and all politics is called to be theological. By and large that is the story of every 
Christian. A story of God, intertwined with the idiosyncrasies of human response. There are a lot of resources on the table to engage with the African (and Kenyan) public in 2021.

\section{CONFLICT OF INTERESTS}

The author has not declared any conflicts of interests.

\section{REFERENCES}

Adogame A (2016). African Christianities and the politics of development from below. HTS: Theological Studies 72(4):1-11.

Bauerschmidt FC (2019). Aquinas. In Cavanaugh, W. T., \& Scott, P. M. (Eds.), Wiley Blackwell companion to political theology. John Wiley \& Sons pp. 54-66.

Beckwith RT (2008). The Old Testament canon of the New Testament church: And its background in early Judaism. Wipf and Stock Publishers.

Bongmba EK (2019). What has Kinshasa to do with Athens? Methodological perspectives on theology and social science in search for a political theology. In: Lauterbach, K., \& Vähäkangas, M. (Eds.), Faith in African lived Christianity: Bridging anthropological and theological perspectives. Brill pp. 195-223.

Bradstock A (2019). The Reformation. In: Cavanaugh, W. T., \& Scott, P. M. (Eds.), Wiley Blackwell companion to political theology. John Wiley and Sons pp. 67-79.

Brueggemann W (2019). Scripture: Old Testament. In Cavanaugh, W T., \& Scott, P. M. (Eds.), Wiley Blackwell companion to political theology. John Wiley \& Sons pp. 15-47.

Cavanaugh WT, Scott PM (Eds.) (2019). Wiley Blackwell companion to political theology. John Wiley \& Sons.

Dube SI (2020). A foray into (study of?) Christian African political theology. Political Theology 21(7):650-666.

Gathogo J (2014). Mau-Mau war and the Church in Kirinyaga, Kenya: Accounting for the tension and conflict (1952-1960). Studia Historiae Ecclesiasticae 40(2):19-41.

Gitari D (1991). Church and politics in Kenya. Transformation 8(3):7-17.

Hallencreutz CF (1988). From Julius Africanus to Augustine in the African: A forgotten link in early African theology. Zambezia 15(1):125.

Hannan S (2021). The camp of God: Reimagining pilgrimage as migrancy in Augustine's city of God. Political Theology 22(1):10-26.

Johnson TM, Zurlo GA, Hickman AW, Crossing PF (2018). Christianity 2018:More African Christians and counting martyrs. International Bulletin of Mission Research 42(1):20-28.

Kaiser WJ (2003). Preaching and teaching from the Old Testament: A guide for the church. Baker Books.

Kamaara E (2000). The role of the Christian church in socio-economic and political development in Kenya. Journal of Third World Studies 17(1):165-176.
Kamaara E (2010). Towards Christian national identity in Africa: A historical perspective to the challenge of ethnicity to the Church in Kenya. Studies in World Christianity 16(2):126-144.

Karanja J (2008). Evangelical attitudes toward democracy in Kenya. In: Ranger, T. O., \& Ranger, T. O. (Eds.), Evangelical Christianity and democracy in Africa (pp. 67-93). Oxford: Oxford University Press.

Katongole $E$ (2011). The sacrifice of Africa: A political theology for Africa. Wm. B. Eerdmans Publishing.

Katongole E (2019). Political theologies of Africa. In: Cavanaugh, W. T. \& Scott, P. M. (Eds.). Wiley Blackwell companion to political theology (pp. 346-359). John Wiley and Sons.

Leeman J (2016). Political Church: The local assembly as Embassy of Christ's rule. InterVarsity Press.

Longman T (2001). Church politics and the genocide in Rwanda. Journal of Religion in Africa 31(2):163-186.

Longman T (2010). Christianity and genocide in Rwanda. Cambridge: Cambridge University Press.

Mbiti JS (1990). African religions and philosophy. Heinemann

Njoya T (1998). The Church as a global society. Reformed World pp. 178-189.

Njoya T (2017). We the people: Thinking heavenly, acting Kenyanly. Nairobi: WordAlive Publishers.

Nietzsche FW (2005). Thus spoke Zarathustra. Oxford University Press.

Okullu H (1991). Church, state, and society in East Africa. Southern Africa Political and Economic Monthly 4(11):4-10.

Parsitau DS (2012). From prophetic voices to lack of voice: Christian churches in Kenya and the dynamics of voice and voicelessness in a multi-religious space. Studia Historiae Ecclesiasticae P 38

Rowland C (2019). Scripture: New Testament. In Cavanaugh, W. T., \& Scott, P. M. (Eds.), Wiley Blackwell companion to political theology (pp. 28-40). John Wiley and Sons.

Schaff $P$ (n.d.). Nicene and post Nicene fathers vol 2. St. Augustine's city of God and Christian doctrine. Grand Rapids, MI: Christian Classics Ethereal Library.

Tulchin AA (2014). Church and state in the French reformation. The Journal of Modern History 86(4):826-861. 